\title{
Monitoring of potential contaminants in beer from the Czech Republic
}

\author{
Jana Olšovská*, Vladimíra Jandovská, Sylvie Běláková, Petra Kubizniaková, Tomáš Vrzal, Karel Štěrba

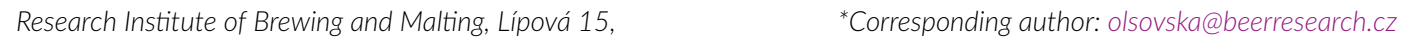 \\ 12044 Prague, Czech Republic \\ tel.: +420224900150
}

\begin{abstract}
The health safety of beer is still a discussed topic. In the Czech Republic, there is a well-developed system for controlling the content of potential beer contaminants, which are regularly attended by a number of large and medium-sized breweries and Analyses are organized by laboratories of the Research Institute of Brewing and Malting. For many years aliphatic chlorinated hydrocarbons, biogenic amines, nitrates, phthalates, ATNC, nitrosamines, polychlorinated biphenyls, polycyclic aromatic hydrocarbons, heavy metals, mycotoxins, coliforms, and recently pesticides in beer have been analyzed. This study summarizes five-year results and extends information about the origin, health risks and hygiene limits of controlled substances and bacteria in beer. The study proves that the level of health safety of beers in the Czech Republic is very high, which is closely related to the high hygiene level of controlled breweries. The number of positive samples was only minor, 8 positive samples were found in 220 beer samples controlled for 44 chemical contaminants. Three positive samples contaminated by coliform bacteria were found among 675 con-
\end{abstract} trolled ones.

Key words: beer contaminants, biogenic amines, n-nitroso compounds, nitrosamine determination, heavy metals, mycotoxins, coliform bacteria

\section{Introduction}

Current environment is highly polluted by various contaminants that circulate in nature and, consequently, in a food chain. Therefore, beer raw materials such as water, barley malt or hops could be a potential source of many toxic substances. While a separation process, which largely eliminates these substances during production, is part of a brewing technology, contaminants may occur in excess concentrations in beer if incorrect procedures or contaminated raw materials are used. In addition, in case of a breach of good technological practice, which results in unwanted chemical or microbiological processes, socalled process contaminants may arise.

Only for a negligible number of potential contaminants of beer was determined a hygiene limit which is legally regulated. It is only a tin in case of canned beer (EC No 1881/2006), and arsenic, aluminum, cadmium, lead, nitrates, NDMA and sum of nitrosamines, whose limits are recommended by JECFA (Joint FAO/WHO Expert Committee on Food Additives), defined as PTWI and PMTDI (Provisional Tolerable Weekly Intake - for contaminants with cumulative effects and Provisional Maximum Tolerable Daily Intake - for contaminants without cumulative effects). The hygiene limits of other potential contaminants can be derived from related matrices, such as water, malt, or food and beverages in general.

In the Czech Republic there is a long-term well-developed system of beer health safety control. The majority of Czech breweries regularly monitor potential contaminants in their beers in laboratories of the Research Institute of Brewing and Malting. The results are compared to the hygiene limits, which are derived from existing or related legislation or recommended limits based on various studies. 
The aim of this study was to evaluate the level of health safety of Czech beer based on a 5-year monitoring of potential beer contaminants, both environmental and process ones. The complex analysis contained determination of aliphatic chlorinated hydrocarbons, biogenic amines, nitrates, phthalates, ATNC (Apparent Total Nitrosamine Compounds), nitrosamines, polychlorinated biphenyls, polycyclic aromatic hydrocarbons, heavy metals and mycotoxins. Coliform bacteria detection was also performed as part of this comprehensive analysis.

\subsection{Aliphatic chlorinated hydrocarbons}

Aliphatic chlorinated hydrocarbons are chlorinated derivatives of non-cyclic hydrocarbons. They are volatile substances, which are broadly used in a wide variety of industries producing solvents, degreasing agents, flame retardants or metal cleaning agents. These substances are dangerous due to their persistence, toxicity and ability to accumulate in biological systems. They are stored in adipose tissue in human body and cause carcinogenic diseases upon prolonged exposure (Poli et al., 2005; Sergejovová and Vaňková, 2000).

The source of chlorinated aliphatic hydrocarbons in beer can be groundwater or surface water, or these compounds can be produced during technological treatment of drinking water in breweries (Horák et al., 1999a).

The determination of organic chlorinated substances in liquid samples is generally carried out by gas chromatography (GC). This may be connected with a solid phase microextraction of the sample (Wypych and Mańko, 2002) or, in case of capillary gas chromatography with purge-and-trap sampling, with an atomic emission detector (Campillo et al., 2004).

\subsection{Biogenic amines}

Biogenic amines are organic nitrogen compounds formed by decarboxylation of free amino acids. They are natural substances of a body and play an indispensable role in some physiological processes. Various foods such as meat, fish, fermented vegetables, but also beverages such as beer and wine contain biogenic amines at above-limit concentrations having a toxic effect on the human body (Anli et al., 2004). Increased concentrations of biogenic amines in beer generally indicate the presence of a bacterial contamination (Bodmer et al., 1999). Therefore, the presence of biogenic amines in beer is considered a marker of a microbial contamination in the brewery and is a proof of its poor hygiene level (Romero R. et al., 2003).

Several methods have been described for the determination of biogenic amines in beer using various analytical instrumentation, such as GC determination with mass spectrometric detection and dispersed microex- traction from liquid to liquid for a sample preparation (Almeida et al., 2012) or using capillary electrophoresis with mass spectrometric detection spectrometry (Daniel et al., 2015).

\subsection{Nitrates}

As such, nitrates are not toxic to adults. Their toxicity is due to their reductive conversion to nitrites, both due to external conditions and, in particular, bacterial effect in the gastrointestinal tract (Manassaram et al., 2006). In addition, nitrites can contribute to the formation of very toxic $\mathrm{N}$ nitroso compounds (see Nitrosamines and ATNC) (Čepička et al., 1991). The source of nitrates in beer can be raw materials, especially water and hops. Especially in case of dry hopping there may be a significant release of nitrates from hops (Kippenberger et al., 2014).

There is a number of methods and techniques for the determination of nitrates in liquid samples, using both UV spectrometry (Armstrong, 1963) and visible spectrum (Doane and Horwáth, 2003). Various older methods for the determination of nitrates in brewing water are based on a colorimetric assay (Sawicki and Scaringelli, 1971; Cataldo et al., 1975).

\subsection{Phthalates}

Esters of phthalic acids or phthalates are the most commonly used plasticizers. As these substances are bound physically rather than covalently in the polymer structure, they are very easy to release from plastics and contaminate the environment to a great extent. Therefore, phthalates in beer can mainly come from raw materials, but can also be released from plastic materials, plastic coated equipment that is in a direct contact with beer or intermediates. Furthermore, they can be transferred to beer from containers intended for transport and storage of beer. Metal caps (crowns) of glass bottles have a plastic seal made from polyvinyl chloride and the alcohol content in beer may aid in releasing the phthalate into beer (Carnol et al., 2017; Ye et al., 2009). Phthalates have proven carcinogenic effects, affect the endocrine system, and may cause premature birth or asthma (Carnol et al., 2017).

Both GC and HPLC methods have been described for the determination of phthalates in beer. The principle of determination of phthalic acid esters in liquid samples by $\mathrm{GC}$ is more common, especially in connection with mass detection. Del Carlo et al., 2008 or Casajuana and Lacorte, 2004 , used this method in combination with solid phase sample extraction. In 2008, Liang et al. published a method for the determination of phthalates by HPLC with UV detection using dispersed microextraction from liquid to liquid (Liang et al., 2008). 


\subsection{Nitrosamines and ATNC}

Nitrosamines are substances belonging to a group of $\mathrm{N}$-nitroso compounds, i.e. substances which have a covalently bonded nitroso group (NO) to a nitrogen atom in their molecule. They are divided into volatile, low volatile and non-volatile ones based on a different vapor pressure. In foods and beverages, the most commonly observed nitrosamines are volatile $\mathrm{N}$-nitrosamines, especially N-nitrosodimethylamine (NDMA). N-nitrosamines are very toxic, their carcinogenic, mutagenic and teratogenic effects have been demonstrated. Non-volatile $\mathrm{N}$-nitrosamines exhibit less harmful effects than volatile $\mathrm{N}$-nitrosamines, but they may be precursors for the formation of volatile $\mathrm{N}$-nitrosamines. The determination of non-volatile $\mathrm{N}$-nitrosamines is relatively difficult and a routine method has not yet been developed. They are therefore determined together with volatile compounds as the apparent sum of all N-nitroso compounds, called ATNC (Fan and Lin, 2018; Lachenmeier and Fügel 2007). However, a new study on the determination of non-volatile N-nitrosamines developed at the RIBM has been published recently (Vrzal and Olšovská, 2019).

In particular, the presence of these substances has been proved in foods that were treated by heat or contained conserved salt. Volatile $\mathrm{N}$-nitrosamines can be found in beer as a product of reaction of amines naturally found in barley with nitrogen oxides from drying air, or they can also be transformed from pesticides. ATNC contained in beer may originate from bacterial contamination of beer or its intermediates (Vrzal and Olšovská, 2016).

An HPLC method with a combination of UV and a chemiluminescent detector was described for the determination of some N-nitrosamines (Kodamatani et al., 2009), as also was HPLC with mass spectrometric detection (Zhao et al., 2006).

\subsection{Polycyclic aromatic hydrocarbons}

Polycyclic aromatic hydrocarbons (PAHs) are compounds composed of two or more condensed benzene rings in different configurations with different substituents. These compounds are spread in the environment as air and water contaminants. A large amount of PAH is released in processing of coal, in incomplete combustion of fossil fuels, and in the incineration of waste or cigarette smoke. In food and beverages, smoking, grilling or roasting increases the content of PAH (Horák et al., 1999b; Plaza-Bolaňos et al., 2010).

PAHs have been shown to have mutagenic and carcinogenic effects, but these effects and their extent depend on a chemical structure. On the other hand, it is not clear whether individual compounds or the sum of all of them lead to fatal toxic effects; it is therefore necessary to monitor the content of all PAHs (Horák et al., 1999c). GC may be used in connection with mass spectrometric detection (Orecchio et al., 2009; King et al., 2004).

\subsection{Polychlorinated biphenyls}

Polychlorinated biphenyls (PCBs) are a mixture of biphenyl molecules substituted with chlorine atoms (Horák et al., 1999c). They are non-polar and have a high chemical, thermal and biological stability, and has been widely used in various industries for their properties (Horák et al., 1999b; Jaraczewska et al., 2006; Falck et al., 1992). PCBs are very harmful substances which cause liver disorders, affect the function of endocrine glands and cognitive functions, have carcinogenic and immunotoxic effects, and cause reproductive and developmental defects. Due to their high thermodynamic stability, their metabolic degradation is considerably slow, and they are therefore deposited in adipose tissue and breast milk (Ahmed, 2003; Safe, 1989).

As a result of toxic effects, the use of PCBs in Europe and North America was restricted and later banned in the 1970s (Jaraczewska, 2006). Nevertheless, these substances are still identified in all environmental components. Contamination of beer with PCB can come from both water and soil, as PCBs are also used as pesticides (Falck et al., 1992).

Polychlorinated biphenyls are determined primarily by GC. Müller et al., used the GC method in connection with a mass spectrometer for the purpose (Müller et al., 2001).

\subsection{Metals}

Beer is a rich source of metals, which are usually contained in low concentrations. Some metals have nutritional properties and are essential for proper functioning of human body at very low concentrations (Donadini et al., 2008). Such elements are called essential micronutrients and include potassium, calcium, magnesium, chromium, copper, nickel, zinc and iron, as well as cobalt or manganese (Tchounwou et al., 2012). Thus, regular consumption of beer in a controlled amount can be also beneficial for the body from the viewpoint of mineral replenishment (Vieira et al., 2014; Pohl, 2008).

Other metals such as tin, aluminum or nickel do not perform biological functions and can cause serious diseases. Arsenic, chromium, cadmium, lead and mercury are a group of metals with a high degree of toxicity (causing systemic damage to organs even at low exposure levels); they belong to the group of priority heavy metals. (Tchounwou et al., 2012).

Metals contained in beer come mainly from raw materials, malt, hops and water that can be contaminated with fertilizer and chemical spraying containing metals 
or as a consequence of ecosystem contamination (Kellner et al., 1982). The concentration of metals may change during the production of beer depending on a technological process and the chemical composition of the intermediates. A decrease of metal concentration during fermentation was observed (Čejka et al., 2009). Another source of metals in beer can be also brewing equipment (pipes, tanks, containers, filtration equipment) or containers for transporting or storing the final product (Pohl, 2008).

Arsenic and all its soluble compounds have toxic effects. Inorganic forms of arsenic can cause skin, lung, liver and bladder cancer (Martin and Griswold, 2009).

Aluminum is abundantly spread in nature; moreover, it may also be found in some pesticides used for hops treatment (Kellner et al., 1984), and it is also the most common material for cans production (Lopez et al., 1998). Aluminum has neurotoxic effects, can cause neurodegenerative diseases such as Alzheimer's disease or bone and liver diseases (Jaishankar et al., 2014).

Various cadmium compounds are contained in air, soils, rocks, coal, mineral fertilizers and pesticides. Cadmium is a very toxic metal that causes kidney dysfunction, hypertension, liver damage, bone fragility and accumulates in biological system (Martin and Griswold, 2009; Pohl, 2008).

Copper is an essential element for proper functioning of a human body, but in high concentrations it can harm the body (Durukan et al., 2011). Copper is widely used in many industries, copper compounds are present in significant concentrations in soils, as copper fungicides are used to protect against fungal diseases (Krofta et al., 2011). Copper at high concentrations may induce vomiting, indigestion, nausea and long-term damage of liver and kidneys (Durukan et al., 2011).

In nature, chromium occurs in compounds only in two permanent oxidation states, trivalent and hexavalent. Trivalent chromium is an important nutritional element, hexavalent chromium is highly toxic and is characterized as a 1st class carcinogen (Vieira et al., 2014; Martin and Griswold, 2009). Chromium sources in beer are mainly raw materials, but contamination from brewing equipment or packaging material may also occur (Vieira et al., 2014).

Iron is an element that is widely distributed throughout the biosphere. It is present in all living organisms and is significantly represented in soil and water. It is essential for the human body primarily because of its involvement in hemoglobin synthesis (Abbaspour et al., 2014). However, at high iron concentrations tissue damage may occur as a result of free radical formation (Lieu et al., 2001), in which iron ions act as a reaction catalyst (Emerit et al., 2001). The iron concentration is controlled especially due to unwanted catalysis of oxidation reactions, which accelerate the sensory ageing process in beer. Usually, the iron concentration is ranging from $<0.01 \mathrm{mg} / \mathrm{L}$ to $0.2 \mathrm{mg} / \mathrm{L}$ (Vanderhaegen et al., 2006).

Mercury may occur in various forms, from elemental mercury to inorganic and organic complexes. These compounds get in the environment from natural sources, but mainly due to a human activity (Kroupová, 2013). Mercury toxicity is dependent on the chemical form of the compound. Elemental mercury, which is not toxic when ingested, can be found in soil and water, where microorganisms can convert it to methylmercury. This belongs to the mercury alkyls, the most toxic mercury compounds. Methylmercury is classified as a potential carcinogen and accumulates in the human body (Horvat and Gibičar, 2005; Martin and Griswold, 2009).

Nickel is a metal used in various industries. It is found in small quantities in the environment. Nickel contamination in beer can come from barley as nickel tends to accumulate in plants. Water may be another source. In small amounts, nickel is essential for proper functioning of a healthy organism, but at higher concentrations it can cause skin allergies or, in extreme cases, lung or prostate cancer (Mahurpawar, 2015).

Lead is a very toxic metal. Lead compounds are spread to all parts of the environment, due to both anthropogenic activity and geochemical processes (Mahurpawar, 2015). Lead is easily accumulated in the environment but is not degraded (Han et al., 2006). The main source of contamination of brewing raw materials is soil and water (Mahurpawar, 2015).

Although tin is widespread in nature, contamination in beer from raw materials, especially barley and hops, is not very common since only a small amount of this metal can be found in plants. However, storage of raw materials or intermediates, such as wort concentrate, in cans may result in increased tin concentration (Biégo et al., 1999). Excessive tin may cause respiratory and nervous system disorders (Mahurpawar, 2015).

Zinc is a metal that, in small quantities, appears to be an essential part of some physiological functions in the human body (Nascentes et al., 2005). It is generally believed that zinc is not very toxic, but excessive zinc intake can cause problems in the nervous, respiratory and digestive systems and, in extreme cases, prostate cancer (Plum et al., 2010).

The majority of described metals are determined using EBC methods based on a principle of atomic absorption spectrometry (AAS) (EBC 9.13.3, 2012; EBC 9.14.3, 2012; EBC 9.20, 2012). Further, the metal concentration in beer can be determined by inductively coupled plasma mass spectrometry (ICP-MS) (Aceto et al., 2000) or electrochemically (Ibanez, et al., 2008; Brainina et al., 2004). 


\subsection{Mycotoxins}

Mycotoxins belong to important toxins of natural origin. They are produced as secondary metabolites by microscopic filamentous fungi. Therefore, their name is a combination of the Greek expression for fungi "mykes" and the Latin word "toxicum", which means poison (Žabka and Jegorov, 2002).

Mycotoxins are chemically and thermally very stable compounds that can occur at all levels of the human and livestock food chain. Contamination can occur during the cultivation of cereals in the field, as well as during storage (Krska et al., 2001).

Mycotoxins can pass from infected barley to malt during a controlled malting process, which creates suitable conditions for their production. In general, mycotoxins are stable up to $170{ }^{\circ} \mathrm{C}$ in a neutral to acidic environment and are therefore nearly inert to the beer brewing process. For this reason, a great deal of attention is being paid to mycotoxin analysis (Wolf-Hall, 2007). The European Food Safety Authority (EFSA) Scientific Committee on Contaminants in the Food Chain has established a tolerable weekly intake (TWI) and a tolerable daily intake (TDI) for some selected mycotoxins (EFSA, 2010). TWI of ochratoxin A is defined as $120 \mathrm{ng} / \mathrm{kg}$ of body weight, TDI for deoxynivalenol is $1 \mu \mathrm{g} / \mathrm{kg}$. Provisionally, TDI for zearalenone is $0.2 \mu \mathrm{g} / \mathrm{kg}$ and for the sum of $\mathrm{T}-2$ and HT- 2 toxin the grouped TDI is $100 \mathrm{ng} / \mathrm{kg}$ of body weight. To summarize, the ordinary control of mycotoxins in beer should involve the determination of the aflatoxin group (B1, B2, G1 and G2), zearalenone, T-2 and HT-2 toxin, deoxynivalenol and ochratoxin A.

\subsection{Pesticides}

The pesticide group includes a wide range of substances that are not only widely used in agriculture, such as plant protection products for a variety of diseases, pests, and weeds, but also for plant growth regulation. Last but not least, pesticides are used for their slowdown effect of premature fruit loss (Jeyaratnam, 1990). Currently, their use ensures crop yields that are necessary to ensure global food production (Aktar et al., 2009). It could be said that pesticides are widespread in all environmental components. Residues of these substances can be found in food, vegetation, workplaces, homes, soil, and water (Aktar et al., 2009). Due to their effect on living organisms, pesticides can negatively affect the human body. They can cause many acute and chronic diseases, such as hormonal disorders, infertility, and abnormal fetal development. Pesticides can also affect the development of a nervous system, which can lead to problems with coordination skills, behavioral disorders or delayed organism development. Some pesticides have a negative effect on the immune system and cause allergies. Others are demonstrable carcinogens and teratogens (Gilden et al., 2010 and Alavanja et al., 2004), the application of which is not currently permitted by legislation (Commission Regulation, 2005).

Currently, the legislation does not define the maximum permissible limits for pesticide residues in beer matrix. However, the hygiene limits exist for hops and barley (Commission Regulation, 2005). Just these two brewing raw materials are the most important source of pesticide residues in beer (Dušek et al., 2018). Therefore, a consistent control of beer in terms of pesticide residues is justified.

\subsection{Coliform bacteria}

The term coliform bacteria (coliforms) applies to Enterobacteriales order, a group of bacteria which form acid and gas by fermenting lactose (at temperature $30-37^{\circ} \mathrm{C}$ within 48 hours). The group involves Escherichia coli (and most of other species of genus Escherichia) and genera Citrobacter, Enterobacter, Klebsiella, Raoultella, and some representatives of genus Serratia. The order Enterobacteriales includes more than 40 bacterial genera found in various environments. Some representatives cause infectious diseases in humans and animals. Many Enterobacteriales species primarily affect digestive tract and can cause diarrheal disease. Furthermore, some enterobacteria/coliforms can cause urinal diseases, wound infections, respiratory tract diseases, etc. (Brenner and Farmer, 2015). Some species of enterobacteria are capable of reducing nitrates to nitrites which successively react with amines and result in the formation of carcinogenic N-nitrosamines. The most critical bacterium in this regard is $S$. pseudoproteus, which is not taxonomically part of coliforms but is monitored in the brewery environment. (Sedláček, 2007). Wort contamination by enterobacteria and coliforms can result in increased concentration of biogenic amines in beer (Smith, 1994; Buňka et al., 2012).

Although coliform bacteria can occur in wort, they are not transferred into finished beer due to their sensitivity to ethanol and acidic pH (Gasarasi et al., 2003; Briggs et al., 2004). Contaminated water or leakages on tubing junctions through which the impurities and bacteria can penetrate to cooled wort can be a source of enterobacteria in brewery plant (Jespersen and Jacobsen, 1996). Enterobacteria present in water and yeast samples detected during a sanitation control are an indicator of deteriorated hygienic conditions and low level of sanitation in the brewery plant (Vaughan et al., 2005). 


\section{MATERIALS AND METHODS}

The contaminants in beer were determined using the following methods:

Aliphatic chlorinated hydrocarbons were determined using GC with headspace injection and ECD (electron capture detector) according to Horák et al. (1999a). The relative expanded uncertainty varies from $20 \%$ to $25 \%$ depending on the analyte, the method makes it possible to determine dichloromethane, 1,1-dichloroethane, 1,2-dichloroethane, trichloromethane, 1,1,1-trichloroethane, 1,1,2-trichloethane, 1,1,2-trichloroethene, 1,1,2,2 tetrachloroethene, carbon tetrachloride, 1,1,1,2-tetrachloroethane and 1,1,2,2-tetrachloroethane (Horák et al., 1999a; EN ISO 10301:1997). The limit of aliphatic chlorinated hydrocarbons in beverages in general is $0.07 \mathrm{mg} / \mathrm{kg}$ (JEFCA, 1996).

Biogenic amines, histamine and tyramine, were determined by a high-performance liquid chromatography (HPLC) method with fluorescence detection according to Jurková et al. (Jurková et al., 2005), where the samples were automatically derivatized in the autosampler with OPA ortho phtalaldehyde (OPA solution is prepared from $0.1 \mathrm{~g}$ of OPA, $1 \mathrm{~mL}$ of methanol p.a., $200 \mu \mathrm{l}$ of 2-mercaptoethanol and $20 \mathrm{~mL}$ of boric buffer $\mathrm{pH} 9.7$ ). The mobile phase $\mathrm{A}$ is $0.01 \mathrm{M} \mathrm{K}_{2} \mathrm{HPO}_{4}$, B is methanol (gradient grade). The chromatographic column used was Luna C18, 250 x $4.6 \mathrm{~mm}, 5 \mu \mathrm{m}$ (Phenomenex, USA), the column temperature was $35^{\circ} \mathrm{C}$, the flow of a mobile phase $0.9 \mathrm{~mL} / \mathrm{min}$. The gradient mode was used for separation $0-10 \mathrm{~min} /$ from $80 \%$ A to $60 \% \mathrm{~A}, 10-25 \mathrm{~min} /$ from $60 \%$ A to $10 \% \mathrm{~A}$, then $25-31.5 \mathrm{~min}$ isocratically/ $10 \% \mathrm{~A}$, and finally $31.5-33.5 \mathrm{~min} /$ from $10 \% \mathrm{~A}$ to $80 \% \mathrm{~A}$. The fluorescence detection was set at $\lambda_{\text {ex }} 330 \mathrm{~nm}$ and $\lambda_{\text {em }}$ $440 \mathrm{~nm}$. The relative expanded uncertainty is $10 \%$ for both analytes. The maximum permissible concentration of histamine in beer is $20 \mathrm{mg} / \mathrm{kg}$, the permissible concentration of histamine in food is in general $100 \mathrm{mg} / \mathrm{kg}$ (JEFCA, 1996).

The nitrate content in beer was determined by the ion chromatography HPLC technique with a spectrometric detection at $210 \mathrm{~nm}$ (Čepička et al., 1991). The relative expanded uncertainty is $4 \%$. The maximum permissible concentration of nitrates in beer respects the limits for drinking water, $50 \mathrm{mg} / \mathrm{L}$ (JEFCA, 1996).

Determination of phthalates, bis-(ethylhexyl)-phthalate and di-n-butyl-phthalate, in beer was carried out using GC with ECD (electron capture detection) when the analytes from beer were extracted into hexane (Horák et al., 1999c). The relative expanded uncertainty is $30 \%$. The permissible concentration of phthalates in beverages in general is $2.0 \mathrm{mg} / \mathrm{kg}$ (JEFCA, 1996).
Determination of ATNC content in beer was performed according to published methods (Walters et al., 1983). The relative expanded uncertainty is $25 \%$.

Sample preparation prior to volatile nitrosamine determination (N-nitrosodimethylamine, N-nitrosodiethylamine, N-nitrosodibutylamine, N-nitrosopiperidine, N-nitrosopyrrolidine, N-nitrosomorpholine) was performed by a vacuum distillation method published previously (Čulík et al., 1989). The gas chromatographic chemiluminescence detection analyses were carried out by Thermo 1310 gas chromatograph with TR-WAX capillary column (30 m, $0.32 \mathrm{~mm}$ ID, $1.0 \mu \mathrm{m}$ film thickness of polyethylene glycol stationary phase). The injection of $5 \mu \mathrm{l}$ of sample was performed at $210^{\circ} \mathrm{C}$ by splitless technique (splitless time $50 \mathrm{~s}$ ). Constant pressure of argon, as a carrier gas, was maintained at $35 \mathrm{kPa}$. The programmed oven temperature during the analysis was set as follows: $40^{\circ} \mathrm{C}(2 \mathrm{~min})-20^{\circ} \mathrm{C} \mathrm{min}^{-1}-210^{\circ} \mathrm{C}(4 \mathrm{~min})$. Interface and the pyrolytic tube temperature were maintained at 250 and $500{ }^{\circ} \mathrm{C}$, respectively. $\mathrm{N}$-nitrosamines were detected by Ellutia 820 TEA chemiluminescence detector with the flow of oxygen at $3.2 \mathrm{~mL} \mathrm{~min}^{-1}$. Concentrations of $\mathrm{N}-\mathrm{ni}$ trosamines in samples were determined according to the peak area ratio of the analyte and internal standard (N-nitrosodipropylamine). The relative expanded uncertainty is $25 \%$. The maximum amount of NDMA in beer by the US Food and Drug Administration is $5 \mu \mathrm{g} / \mathrm{L}$ (Fan and Lin, 2018; US FDA, 2005). According to the recommendations of the Czech Beer and Malt Association, NDMA in beer should not exceed $0.5 \mu \mathrm{g} / \mathrm{kg}$ and the sum of six nitrosamines $1.5 \mu \mathrm{g} / \mathrm{kg}$ (Vrzal and Olšovská, 2016).

For a regular control of beer, individual PAHs (benzo(a)anthracene, benzo(b)fluoranthene, benzo(k) fluoranthene, chrysene, dibenzo(a,h)anthracene, benzo(a)pyrene, indeno(1,2,3-cd)pyrene, dibenzo(a,i)pyrene and dibenzo(a,h)pyrene) were determined by the method of Horák et al. (Horák et al., 1999c). The relative expanded uncertainty is $15 \%$. The hygiene limit of individual substances $0.5 \mu \mathrm{g} / \mathrm{L}$ and the total content of all substances $5 \mu \mathrm{g} / \mathrm{L}$ in beer is derived from recommendation for beverages in general (JEFCA, 1996).

The determination of PCBs in beer was carried out by GC with ECD when the analytes from beer were extracted into hexane (Horák et al., 1999c). The relative expanded uncertainty is $25 \%$. The permissible concentration of phthalates in beverages is $0.5 \mathrm{mg} / \mathrm{kg}$ (JECFA, 1996).

Concentrations of arsenic, aluminum, cadmium, copper, chromium, iron, nickel, lead, tin and zinc were determined by flame or electrothermal atomic absorption spectrometry according to EBC (EBC 9.13.3, 2012; EBC 9.14.3, 2012; EBC $9.20,2012)$. The relative expanded uncertainty varies from $6 \%$ to $20 \%$ depending on the measured metal (see Table 1 ). 
Mercury was determined using a cold vapor-based method on an AMA 254 analyzer (Száková et al., 2004). The relative expanded uncertainty is $6 \%$.

The hygiene limits of monitored metals are given in Table 1. They are derived from JEFCA, the maximum concentration of tin in canned beer $100 \mathrm{mg} / \mathrm{kg}$ is given by Regulation 1881/2006/ES.

Analyses of selected mycotoxins were performed by HPLC-MS/MS and Ultra Performance Liquid Chromatography (UPLC) methods with PDA and FLR detection (Photo Diode Array and Fluorescence) after previous purification through an immunoaffinity column (Běláková et al., 2011; Benešová et al., 2012; Zollner and Mayer-Helm, 2006). There is as yet no hygiene limit for mycotoxins in beer

\section{Results and Discussion}

Table 1 summarizes the groups of listed analytes (aliphatic chlorinated hydrocarbons, biogenic amines, nitrates, N-nitrosamines, ATNC, PAH, PCB and metals), the limit of quantification (LOQ), the method uncertainty and the checked hygiene limit. Table 2 summarizes the results of beer samples from 2014 to 2018, in which the above-mentioned contaminants were determined.

Limiting values for coliform bacteria in beer are established by the act "298/1997 Coll." covering the microbiological requirements for food. The limiting value for coliform bacteria is $100 \mathrm{CFU}$ (colony-forming unit) per $\mathrm{mL}$. Table 4 summarizes the results of analyses on the presence of coliform bacteria from 2014 to 2018. The number of samples per year, the number of samples exceeding the limiting value and the ratio of positive results are listed. This means that the coliform bacteria were detected, but as long as the limiting value for CFU is not exceeded, the sample meets legislative requirements.

During the five-year monitoring, 220 samples of Czech beers were tested. These were mainly lagers, but also non-alcoholic beers and beer mixes. In 2014, one sample of a non-alcoholic beer exceeded the limit of lead concentration. In 2015, over-limit values of N-nitrosodimethylamine, N-nitrosodiethylamine, N-nitrosopiperidine and total $\mathrm{N}$-nitrosamines were found in one sample of a beer mix. The following year, all checked samples were in compliance with the required standards and regulations.

Three samples of beer from a total of 49 analyzed in 2017 were found to exceed the defined hygiene limits. Higher concentrations of nitrates were measured in dark and semi-dark special beers, and the above-limit levels of histamine were detected in one sample of dark lager. In 2018 a total of 51 samples were analyzed, of which one sample of a flavored non-alcoholic beer and two pale lagers contained the over-limit amounts of chromium. The nitrate content was exceeded in 2018 in one sample of a special dark beer. To summarize, only 8 samples from the total of 220 samples, exceeded the hygiene limit (see Table 2).

Ochratoxin A was the most frequently detected mycotoxin. This compound was annually identified in at least $70 \%$ of the analyzed samples, in 2017 , it was even detected in 45 of 49 samples in total. However, the concentration range of ochratoxin A was ranging only from 1 to $141 \mathrm{ng} / \mathrm{L}$, when compared to the TWI of ochratoxin A. Other substances with significant proportions of positive findings are deoxynivalenol, T-2 and HT- 2 toxin. Altogether $77.2 \%$ of positive samples of deoxynivalenol were found, which ranged from 2.01 to $29.3 \mathrm{ng} / \mathrm{L}$. The number of beer samples contaminated with T-2 and HT-2 toxin in 2016 and 2018 ranged from $16 \%$ to $88.4 \%$, respectively. The maximum concentration for both toxins was $1.8 \mathrm{ng} / \mathrm{L}$. The content of zearalenone was determined in only one eer sample in the amount of $0.41 \mathrm{ng} / \mathrm{L}$ in 2016. The aflatoxin group was not identified in any controlled samples of beer over the period of 2014-2018 (see Table 3).

Microbiological analysis was carried out on 675 beer samples from 2014 to 2018. Excessive coliform values were detected in only one sample in 2017 when 116 samples were checked and in 2018 in two samples out of 162 (see Table 4). This implies that the hygiene standards of the controlled breweries are very high and this finding follows the analytical results where products of microbial contamination were not found in beers.

\section{Conclusion}

The purpose of this work was to show the efficient system of the beer control in the Czech Republic from the view of health safety, and publish the results of a longterm study. Based on the results of a five-year monitoring, we can conclude that most of the checked samples did not contain significant concentrations of any described contaminating toxic substances. The number of positive samples was minimal. Furthermore, these samples were detected due to the regular monitoring. Subsequently, the contamination was no longer confirmed in the control sample measurement, indicating most probably the randomness of the result. In the second case, trouble in the technological process was detected in time, and removed on the basis of this finding.

Due to the increasing number of microbreweries, the development of new technologies and the usage of unconventional raw material, the regular checking of the health safety of beer should become a matter of course, 
Table 1 Monitored analytes, LOQ, relative expanded uncertainty and checked hygiene limits

(aliphatic chlorinated hydrocarbons, biogenic amines, nitrates, phthalates, N-nitrosamines, ATNC, PAH, PCB and metals)

\begin{tabular}{|c|c|c|c|c|}
\hline chemical group & analyte & LOQ & $\begin{array}{l}\text { relative expanded } \\
\text { uncertainty } \%\end{array}$ & hygiene limit* \\
\hline \multirow{11}{*}{$\begin{array}{c}\text { aliphatic chlorinated } \\
\text { hydrocarbons }\end{array}$} & dichloromethane & $2 \mu \mathrm{g} / \mathrm{L}$ & \multirow{11}{*}{$20-25$} & \multirow{11}{*}{$0.07 \mathrm{mg} / \mathrm{kg}$} \\
\hline & 1,1-dichloroethane & $1 \mu \mathrm{g} / \mathrm{L}$ & & \\
\hline & 1,2-dichloroethane & $1 \mu \mathrm{g} / \mathrm{L}$ & & \\
\hline & trichloromethane & $1 \mu \mathrm{g} / \mathrm{L}$ & & \\
\hline & 1,1,1-trichloroethane & $1 \mu \mathrm{g} / \mathrm{L}$ & & \\
\hline & 1,1,2-trichloroethane & $2 \mu \mathrm{g} / \mathrm{L}$ & & \\
\hline & 1,1,2-trichloroethene & $1 \mu \mathrm{g} / \mathrm{L}$ & & \\
\hline & 1,1,2,2 tetrachloroethene & $1 \mu \mathrm{g} / \mathrm{L}$ & & \\
\hline & carbon tetrachloride & $1 \mu \mathrm{g} / \mathrm{L}$ & & \\
\hline & 1,1,1,2-tetrachloroethane & $1 \mu \mathrm{g} / \mathrm{L}$ & & \\
\hline & 1,1,2,2-tetrachloroethane & $3 \mu \mathrm{g} / \mathrm{L}$ & & \\
\hline \multirow{2}{*}{ biogenic amines } & histamine & $1 \mathrm{mg} / \mathrm{kg}$ & 10 & $20 \mathrm{mg} / \mathrm{kg}$ \\
\hline & tyramine & $2 \mathrm{mg} / \mathrm{kg}$ & 10 & $100 \mathrm{mg} / \mathrm{kg}$ \\
\hline nitrates & nitrates & $0.5 \mathrm{mg} / \mathrm{kg}$ & 4 & $50 \mathrm{mg} / \mathrm{kg}$ \\
\hline \multirow{2}{*}{ phthalates } & bis-(ethylhexyl)-phthalate & \multirow{2}{*}{$0.01 \mathrm{mg} / \mathrm{L}$} & \multirow{2}{*}{30} & \multirow{2}{*}{$2.0 \mathrm{mg} / \mathrm{kg}$} \\
\hline & di-n-butyl-phthalate & & & \\
\hline \multirow{7}{*}{$\mathrm{N}$-nitrosamines } & N-nitrosodimethylamine & \multirow{7}{*}{$0.2 \mu \mathrm{g} / \mathrm{kg}$} & \multirow{7}{*}{25} & \multirow{6}{*}{$0.5 \mu \mathrm{g} / \mathrm{kg}$} \\
\hline & $\mathrm{N}$-nitrosodiethylamine & & & \\
\hline & $\mathrm{N}$ nitrosodibutylamine & & & \\
\hline & $\mathrm{N}$-nitrosopiperidine & & & \\
\hline & $\mathrm{N}$-nitrosopyrrolidine & & & \\
\hline & N-nitrosomorfoline & & & \\
\hline & sum of $\mathrm{N}$-nitrosamines & & & $1.5 \mu \mathrm{g} / \mathrm{kg}$ \\
\hline ATNC & ATNC & $20 \mu \mathrm{g}$ N-NO/kg & 25 & \\
\hline \multirow{10}{*}{ PAH } & benzo(a)anthracene & $10 \mathrm{ng} / \mathrm{L}$ & \multirow{10}{*}{15} & \multirow{9}{*}{$0.5 \mu \mathrm{g} / \mathrm{L}$} \\
\hline & benzo(b)fluoranthene & $30 \mathrm{ng} / \mathrm{L}$ & & \\
\hline & benzo(k)fluoranthene & $50 \mathrm{ng} / \mathrm{L}$ & & \\
\hline & chrysene & $10 \mathrm{ng} / \mathrm{L}$ & & \\
\hline & dibenzo(a,h)anthracene & $40 \mathrm{ng} / \mathrm{L}$ & & \\
\hline & benzo(a)pyrene & $20 \mathrm{ng} / \mathrm{L}$ & & \\
\hline & indeno(1,2,3-cd)pyrene & $30 \mathrm{ng} / \mathrm{L}$ & & \\
\hline & dibenzo(a,i)pyrene & $20 \mathrm{ng} / \mathrm{L}$ & & \\
\hline & dibenzo(a,h)pyrene & $50 \mathrm{ng} / \mathrm{L}$ & & \\
\hline & sum of PAHs & & & $5 \mu \mathrm{g} / \mathrm{L}$ \\
\hline PCB & & $10 \mathrm{ng} / \mathrm{L}$ & 25 & $0.5 \mathrm{mg} / \mathrm{kg}$ \\
\hline \multirow{11}{*}{ metals } & As & $0.05 \mathrm{mg} / \mathrm{L}$ & 10 & $0.2 \mathrm{mg} / \mathrm{kg}$ \\
\hline & $\mathrm{Al}$ & $0.2 \mathrm{mg} / \mathrm{L}$ & 8 & $5.0 \mathrm{mg} / \mathrm{kg}$ \\
\hline & $\mathrm{Cd}$ & $0.005 \mathrm{mg} / \mathrm{L}$ & 8 & 0.05 mg/kg \\
\hline & $\mathrm{Cu}$ & $0.01 \mathrm{mg} / \mathrm{L}$ & 15 & $5.0 \mathrm{mg} / \mathrm{kg}$ \\
\hline & $\mathrm{Cr}$ & $0.02 \mathrm{mg} / \mathrm{L}$ & 8 & $0.1 \mathrm{mg} / \mathrm{kg}$ \\
\hline & $\mathrm{Fe}$ & $0.01 \mathrm{mg} / \mathrm{L}$ & 20 & $5.0 \mathrm{mg} / \mathrm{kg}$ \\
\hline & $\mathrm{Ni}$ & $0.02 \mathrm{mg} / \mathrm{L}$ & 8 & $1.0 \mathrm{mg} / \mathrm{kg}$ \\
\hline & $\mathrm{Pb}$ & $0.03 \mathrm{mg} / \mathrm{L}$ & 8 & $0.05 \mathrm{mg} / \mathrm{kg}$ \\
\hline & Sn & $0.5 \mathrm{mg} / \mathrm{L}$ & 10 & 100 mg/kg \\
\hline & $\mathrm{Zn}$ & $0.01 \mathrm{mg} / \mathrm{L}$ & 6 & $50 \mathrm{mg} / \mathrm{kg}$ \\
\hline & $\mathrm{Hg}$ & $0.0005 \mathrm{mg} / \mathrm{L}$ & 6 & $0.003 \mathrm{mg} / \mathrm{kg}$ \\
\hline
\end{tabular}


Table 2 Results of determined compounds listed in Table 1 in monitored beer samples ranging from 2014 to 2018

\begin{tabular}{|c|c|c|c|c|}
\hline year & number of samples & $\begin{array}{c}\text { number of unsatisfactory } \\
\text { samples }\end{array}$ & $\begin{array}{c}\text { relative ratio of } \\
\text { unsatisfactory samples } \\
\%\end{array}$ & $\begin{array}{c}\text { analyte above the limit } \\
\text { found }\end{array}$ \\
\hline 2014 & 40 & 1 & 2.5 & Pb \\
\hline 2015 & 45 & 1 & 2.2 & $\begin{array}{c}\text { NDMA, NDEA, NPID, } \\
\text { sum of nitrosamines }\end{array}$ \\
\hline 2016 & 35 & 0 & 0 & histamine, nitrates \\
\hline 2017 & 49 & 3 & 6.1 & Cr, nitrates \\
\hline 2018 & 51 & 3 & 5.9 & \\
\hline
\end{tabular}

Table 3 Results of mycotoxin determination in monitored beer samples ranging from 2014 to 2018

\begin{tabular}{|c|c|c|c|c|c|c|}
\hline year & mycotoxins & number of samples & positive samples & $\begin{array}{c}\text { relative ratio of } \\
\text { positives } \\
\%\end{array}$ & $\begin{array}{l}\text { range } \\
\mathrm{ng} / \mathrm{L}^{* *} \\
\mu \mathrm{g} / \mathrm{L}^{* * *}\end{array}$ & $\begin{array}{l}\text { exceeding the } \\
\text { limit* }\end{array}$ \\
\hline \multirow{5}{*}{2014} & aflatoxins & 35 & 0 & 0.0 & - & \\
\hline & deoxynivalenol & 43 & 28 & 65.1 & $2.33-22.5$ & no \\
\hline & zearalenone & 27 & 0 & 0.0 & - & \\
\hline & $\begin{array}{l}\mathrm{T}-2 \text { and } \mathrm{HT}-2 \\
\text { mycotoxins }\end{array}$ & 24 & 8 & 33.3 & $0.17-0.71$ & no \\
\hline & ochratoxin A & 47 & 33 & 70.2 & $1.4-141$ & no \\
\hline \multirow{5}{*}{2015} & aflatoxins & 37 & 0 & 0.0 & - & \\
\hline & deoxynivalenol & 47 & 14 & 29.8 & $2.01-29.3$ & no \\
\hline & zearalenone & 35 & 0 & 0.0 & - & \\
\hline & $\begin{array}{l}\mathrm{T}-2 \text { and } \mathrm{HT}-2 \\
\text { mycotoxins }\end{array}$ & 35 & 18 & 51.4 & $0.04-0.9$ & no \\
\hline & ochratoxin A & 50 & 35 & 70.0 & $1.8-28.8$ & no \\
\hline \multirow{5}{*}{2016} & aflatoxins & 38 & 0 & 0.0 & - & \\
\hline & deoxynivalenol & 73 & 24 & 32.9 & $2.12-10.7$ & no \\
\hline & zearalenone & 25 & 1 & 4.0 & 0.41 & no \\
\hline & $\begin{array}{l}\mathrm{T}-2 \text { and } \mathrm{HT}-2 \\
\text { mycotoxins }\end{array}$ & 25 & 4 & 16.0 & $0.04-0.82$ & no \\
\hline & ochratoxin A & 78 & 62 & 79.5 & $1-134$ & no \\
\hline \multirow{5}{*}{2017} & aflatoxins & 35 & 0 & 0.0 & - & \\
\hline & deoxynivalenol & 50 & 29 & 58.0 & $2.09-13.9$ & no \\
\hline & zearalenone & 30 & 0 & 0.0 & - & \\
\hline & $\begin{array}{l}\text { T-2 a HT-2 myco- } \\
\text { toxins }\end{array}$ & 29 & 7 & 24.1 & $0.3-0.85$ & no \\
\hline & ochratoxin A & 49 & 45 & 91.8 & $1.3-77.3$ & no \\
\hline \multirow{5}{*}{2018} & aflatoxins & 55 & 0 & 0.0 & - & \\
\hline & deoxynivalenol & 57 & 44 & 77.2 & $2.03-17.0$ & no \\
\hline & zearalenone & 40 & 0 & 0.0 & - & \\
\hline & $\begin{array}{l}\mathrm{T}-2 \text { and } \mathrm{HT}-2 \\
\text { mycotoxins }\end{array}$ & 43 & 38 & 88.4 & $0.05-1.8$ & no \\
\hline & ochratoxin A & 67 & 51 & 76.1 & $1.4-56.1$ & no \\
\hline
\end{tabular}

${ }^{*}$ The above-limit value was derived from the highest found concentration of a given mycotoxin, their TWI or TDI and recommended

consumption of beer under moderate drinking conditions, which is two $0.5 \mathrm{~L}$ beer for men and two $0.3 \mathrm{~L}$ beer for women (Poli et al.,2013).

** units $n g / L$ apply to aflatoxins and ochratoxin A

${ }^{* * *}$ units $\mu \mathrm{g} / \mathrm{L}$ apply to deoxynivalenol, zearalenone, and T-2 and HT-2 mycotoxins 
Table 4 The results of microbiological analyses of samples of beers from the years 2014 to 2018

\begin{tabular}{|c|c|c|c|}
\hline year & number of samples determined & $\begin{array}{c}\text { the proportion of positive samples } \\
\%\end{array}$ & \begin{tabular}{c} 
the number of over-limit samples \\
\hline 2014
\end{tabular}$\quad 97$ \\
\hline 2015 & 172 & 14.4 & 0 \\
\hline 2016 & 128 & 13.9 & 0 \\
\hline 2017 & 116 & 9.4 & 1 \\
\hline 2018 & 162 & 9.5 & 2 \\
\hline
\end{tabular}

so that the beer remains in compliance with regulations of safe food. Finally, systematic checking of beer contaminants can help the breweries and the whole brewing industry to defend themselves against the increasing number of cases which, as the study suggests, are unjustified and harm the reputation of Czech brewing and brewing in general.

\section{Acknowledgments}

The results were obtained with the support of the Ministry of Education, Youth and Sports of the Czech Republic - Research Sensory Center in Prague and Research and Development Center - Sustainability and Development (L01312).

\section{References}

Abbaspour, N., Hurrell, R., Kelishadi, R., 2014: Review on iron and its importance for human health. J. Res. Med. Sci. 19(2): 164-174.

Aceto, M., Abollino, O., Bruzzoniti, M. C., Mentasti, E., Sarzanini, C., Malandrino, M., 2002: Determination of metals in wine with atomic spectroscopy (flame-AAS, GF-AAS and ICP-AES); a review. Food Additives \& Contaminants, 19(2): 126-133. DOI: 10.1080/02652030110071336

Ahmed, F.E., 2003: Analysis of polychlorinated biphenyls in food products. Trends Anal. Chem. 22(3): 170-185. https://doi.org/10.1016/ S0165-9936(03)00305-4

Aktar, M. W., Sengupta, D., Chowdhury, A., 2009: Impact of pesticides use in agriculture: their benefits and hazards. Interdiscip. Toxicol. 2(1): 1-12. https://doi.org/10.2478/v10102-009-0001-7

Alavanja, M. C. R., Hoppin, J. A., Kamel, F., 2004: Health Effects of Chronic Pesticide Exposure: Cancer and Neurotoxicity. Annu. Rev. Public Health 25: 155-197. https://doi.org/10.1146/annurev. publhealth.25.101802.123020

Almeida, C., Fernandes, J. O., Cunha, S. C., 2012: A novel dispersive liquid-liquid microextraction (DLLME) gas chromatography-mass spectrometry (GC-MS) method for the determination of eighteen biogenic amines in beer. Food Cont. 25(1): 380-388. https://doi. org/10.1016/j.foodcont.2011.10.052

Anl, R. E., Vural, N., Yllmaz, S., Vuralý, H., 2004: The determination of biogenic amines in Turkish red wines. J. Food Comp. Anal., 17(1): 53-62. https://doi.org/10.1016/S0889-1575(03)00104-2

Armstrong, F. A. J., 1963: Determination of Nitrate in Water Ultraviolet Spectrophotometry. Anal. Chem. 35(9): 1292-1294.

Běláková, S., Benešová, K.; Mikulíková, R.; Svoboda, Z., 2011: Determination of ochratoxin $\mathrm{A}$ in brewing materials and beer by ultra performance liquid chromatography with fluorescence detection. Food Chem. 126(1): 321-325. https://doi.org/10.1016/j.foodchem.2010.10.062

Benešová, K., Běláková, S.; Mikulíková, R.; Svoboda, Z., 2012: Monitoring of selected aflatoxins in brewing materials and beer by liquid chromatography/mass specrometry. Food Control 25(2): 626-630. https:// doi.org/10.1016/j.foodcont.2011.11.033

Biégo, G. H., Joyeux, M., Hartemann, P., Debry, G., 1999: Determination of Dietary Tin Intake in an Adult French Citizen. Arch. Environ. Contam. Toxicol. 36(2): 227-232. https://doi.org/10.1007/s002449900465

Bodmer, S., Imark, C., Kneubühl, M., 1999: Biogenic amines in foods: Histamine and food processing. Inflamm. Res. 48(6): 296-300. https:// doi.org/10.1007/s000110050463

Brainina, K. Z., Stozhko, N. Y., Belysheva, G. M., Inzhevatova, O. V., Kolyadina, L. I., Cremisini, C., Galletti, M., 2004: Determination of heavy metals in wines by anodic stripping voltammetry with thick-film modified electrode. Anal. Chim. Acta 514(2): 227-234. https://doi. org/10.1016/j.aca.2004.03.047

Brenner, D. J., Farmer III, J. J., 2015: Enterobacteriaceae. In: Whitman, W.B., editor, Bergey's Manual of Systematics of Archaea and Bacteria. John Wiley \& Sons, Inc., in association with Bergey's Manual Trust, https://doi.org/10.1002/9781118960608.fbm00222

Briggs, D. E., Boulton, C. A., Brookes, P. A., Stevens, R., 2004: Brewing: science and practice. Woodhead Publishing, Cambridge UK/CRC Press, Boca Raton, Florida, USA, 881 pp, ISBN 0-8493-2547-1

Buňka, F., Budinský, P., Čechová, M., Drienovský, V., Pachlová, V., Matoulková, D., Kubáň, V., Buňková, L., 2012: Content of biogenic amines and polyamines in beers from the Czech Republic. J. Inst. Brew. 118(2): 213-216. https://doi.org/10.1002/jib.31

Campillo, N., Viñas, P., López-García I., Aguinaga, N., Hernández-Córdoba M., 2004: Purge-and-trap capillary gas chromatography with atomic emission detection for volatile halogenated organic compounds determination in waters and beverages. J. Chromatogr. A 1035(1): 1-8. https://doi.org/10.1016/j.chroma.2004.02.029

Carnol, L., Schummer, C., Moris, G., 2017: Quantification of six phthalates and one adipate in luxembourgish beer using HS-SPME-GC/ MS. Food. Anal. Methods 10(2):298-309. https://doi.org/10.1007/ s12161-016-0583-6

Casajuana, N., Lacorte, S., 2004: New Methodology for the Determination od Phthalate Esters, Bisphenol A, Bisphenol A Diglycidyl Ether, and Nonylphenol in Commercial Whole Milk Samples. J. Agric. Food. Chem. 52(12): 3702-3707. https://doi.org/10.1021/jf040027s

Cataldo, D. A., Maroon, M., Schrader, L. E., Youngs, V. L., 1975: Rapid colorimetric determination of nitrate in plant tissue by nitration of salicylic acid. Comm. Soil. Sci. Plant. Anal. 6(1): 71-80.

Commission Regulation (2005) (EU) no. 396/2005 on maximum residue levels of pesticides in or on food and feed of plant and animal origin and amending Council Directive 91/414/EEC, 16 March

Čejka P., Dvořák J., Čulík J., Jurková M., Horák T., Kellner V., 2009: The Behaviour of Toxic Metals in The Brewing Process. Kvasný Průmysl 55(4): 100-105. https://doi.org/10.18832/kp2009010 
Čepička, J., Baudyš, P., Víznerová, E., Krausová, J., 1991: Nitrate content in brewing waters and beers of eastern bohemian breweries. Kvasný Průmysl 37(8-9): 230-234. https://doi.org/10.18832/kp1991024

Čulík, J., Kellner, V., Špinar, B., Prokeš, J., Basařová, G., 1989: Těkavé N-nitrosaminy ve sladu I. Vliv pesticidů a dusíkatých hnojiv aplikovaných ve vegetačním období na obsah těkavých N-nitrosaminů v ječmeni a sladu. Kvasný Průmysl 35(10): 289-292. https://doi. org/10.18832/kp1989037

Daniel, D., Dos Santos, V. B., Vidal, D. T. R., do Lago, C. L., 2015: Determination of biogenic amines in beer and wine by capillary electrophoresis-tandem mass spectrometry. J. Chromatogr. A 1416:121-128. https://doi.org/10.1016/j.chroma.2015.08.065

Del Carlo, M., Pepe, A., Sacchetti, G., Compagnone, D., Mastrocola, D., Cichelli, A., 2008: Determination of phthalate esters in wine using solid-phase extraction and gas chromatography-mass spectrometry. Food Chem. 111(3): 771-777. https://doi.org/10.1016/j.foodchem.2008.04.065

Doane, T. A., Horwáth, W. R., 2003: Spectrophotometric Determination of Nitrate with a Single Reagent. Anal. Lett. 36(12): 2713-2722. https://doi.org/10.1081/AL-120024647

Donadini, G., Spalla, S., Beone, G. M., 2008: Arsenic, cadmium and lead in beers from the Italian market. J. Inst. Brew. 114(4): 283-288. https://doi.org/10.1002/j.2050-0416.2008.tb00770.x

Durukan, I., Şahin, C. A., Şatıroğlu, N., Bektaş, S., 2011: Determination of iron and copper in food samples by flow injection cloud point extraction flame atomic absorption spectrometry. Microchem. J. 99(1): 159-163. https://doi.org/10.1016/j.microc.2011.04.016

Dušek, M., Jandovská, V., Olšovská, J., 2018: Tracking, Behavior and Fate of 58 Pesticides Originated from Hops during Beer Brewing. J. Agric. Food Chem. 66(38): 10113-10121. https://doi.org/10.1021/acs.jafc.8b03416

EBC 9.13.3 Analytica-EBC. Iron in Beer by Atomic Absorption Spectrophotometry (IM). Fachverlag Hans Carl, Nürnberg, Germany, 2012.

EBC 9.14.3 Analytica-EBC. Copper in Beer by Atomic Absorption Spectrophotometry (IM). Fachverlag Hans Carl, Nürnberg, Germany, 2012.

EBC 9.20 Analytica-EBC. Zinc in Beer by Atomic Absorption Spectrophotometry (IM). Fachverlag Hans Carl, Nürnberg, Germany, 2012.

EC No 1881/2006: Commission Regulation (EC) No 1881/2006 of 19 December 2006 setting maximum levels for certain contaminants in foodstuffs.

EFSA, 2010: Statement on recent scientific information on the toxicity of Ochratoxin A, EFSA Journal 2010; 8(6):1626. https://doi. org/10.2903/j.efsa.2010.1626

Emerit, J., Beaumont, C., Trivin, F., 2001: Iron metabolism, free radicals, and oxidative injury. Biomen. Pharmacother. 55: 333-339. https:// doi.org/10.3390/nu9070671

EN ISO 10301:1997. Water quality - Determination of highly volatile halogenated hydrocarbons - Gas-chromatographic methods. Geneva, Switzerland: International Organization for Standardization, 1997.

Falck, F., Ricci, A., Wolff, M. S., Godbold, J., Deckers, P., 1992: Pesticides and polychlorinated biphenyl residues in human breast lipids and their relation to breast cancer. Arch. Environ. Health. 47(2): 143-146.

Fan C.-C., Lin T.-F., 2018: N-nitrosamines in drinking water and beer: Detection and risk assessment. Chemosphere 200: 48-56. https://doi. org/10.1016/j.chemosphere.2018.02.025

Gasarasi, G., Kelgtermans, M., Verstrepen, K. J., van Roy, J., Delvaux, F. R., Derdelinckx, G., 2003: Occurrence of biogenic amines in beer: causes and proposal remedies. Monatssch. Brauwiss. 56(3/4): 58-63.

Gilden, R. C., Huffling, K., Sattler, B., 2010: Pesticides and Health Risks. J. Obstet. Gynecol. Neonatal. Nurs. 39(1): 103-110. https://doi. org/10.1111/j.1552-6909.2009.01092.x

Han, R., Li, H., Li, Y., Zhang, J., Xiao, H., Shi, J., 2006: Biosorption of copper and lead ions by waste beer yeast. J. Hazard. Mater. 137(3): 1569-
1576. https://doi.org/10.1016/j.jhazmat.2006.04.045

Horák, T., Čulík, J., Jurková, M., Kellner, V., 1999a: The determination of aliphatic chlorocarbons in beer. Kvasný Průmysl 45(12): 317-320. https://doi.org/10.18832/kp1999023

Horák T., Jurková M., Čulík J., Kellner V., 1999b: Polychlorinated biphenyls and polycyclic aromatic hydrocarbons in beer. Kvasný Průmysl 45(6): 159-161. https://doi.org/10.18832/kp1999012

Horák T., Jurková M., Čulík J., Kellner V., 1999c: The determination of polycyclic aromatic hydrocarbons and polychlorinated biphenyls in beer. Kvasný Průmysl 45(7-8): 190-192. https://doi.org/10.18832/ kp1999015

Horvat M., Gibičar D., 2005: Speciation of Mercury: Environment, Food, Clinical, and Occupational Health. in Cornelis, R., Caruso, J., Crews, H., Heumann, K.: Handbook of Elemental Speciation II - Species in the Environment, Food, Medicine and Occupational Health. John Wiley \& Sons, Ltd., England. https://doi.org/10.1002/0470856009.ch2l

Ibanez, J. G., Carreon-Alvarez, A., Barcena-Soto, M., Casillas, N., 2008: Metals in alcoholic beverages: A review of sources, effects, concentrations, removal, speciation, and analysis. J. Food. Compos. Anal. 21(8): 672-683. https://doi.org/10.1016/j.jfca.2008.06.005

Jaraczewska, K., Lulek, J., Covaci, A., Voorspoels, S., Kaluba-Skotarczak, A., Drews, K., Schepens, P., 2006: Distribution of polychlorinated biphenyls, organochlorine pesticides and polybrominated diphenyl ethers in human umbilical cord serum, maternal serum and milk from Wielkopolska region, Poland. Sci. Total Environ. 372(1): 20-31. https://doi.org/10.1016/j.scitotenv.2006.03.030

Jaishankar, M., Tseten, T., Anbalagan, N., Mathew, B. B., Beeregowda, K. N., 2014: Toxicity, mechanism and health effects of some heavy metals. Interdiscip. Toxicol. 7(2): 60-72. https://doi.org/10.2478/ intox-2014-0009

JECFA - Summary of evaluations performed by JEFCA (the Joint FAO/WHO Expert Committtee on Food Additives); editor: ILSI press 1996, garanted by: FAO/IPCS - International Programme on Chemical Safety.

Jespersen, L., Jakobsen, M., 1996: Specific spoilage organisms in breweries and laboratory media for their detection. Int. J. Food Microbiol., 33(1): 139-155. https://doi.org/10.1016/0168-1605(96)01154-3

Jeyaratnam, J., 1990: Acute pesticide poisoning: a major global health problem. World Health Stat. Q. 43(3): 139-44.

Jurková, M., Kellner, V., Horák, T., Čejka, P., Čulík, J., 2005: The HPLC determination of biogenic amines in beer by solid phase extraction (SPE) and automatic precolumn derivatization. Proceedings of the 30th EBC Congress, Prague. ISBN 90-70143-23-2/ISBN 978-90-70143$23-7$

Kellner, V., Čejka, P., Frantík, F., 1982: Stanovení kovů v pivu a pivovarských surovinách. Kvasný Průmysl 28(7): 145-149. https://doi. org/10.18832/kp1982029

Kellner, V., Čejka, P., Frantík, F., 1984: Problematika kovů v pivu - Al, As, Cd, Pb. Kvasný Průmysl 30(6): 121-124. https://doi.org/10.18832/ kp1984023

King, A. J., Readman, J. W., Zhou, J. L., 2004: Determination of polycyclic aromatic hydrocarbons in water by solid-phase microextraction-gas chromatography-mass spectrometry. Anal. Chim. Acta 523(2): 259267. https://doi.org/10.1016/j.aca.2004.07.050

Kippenberger, M., Hanke, S., Biendl, M., Stettner, G., Lagemann, A., 2014: Transfer of nitrate and various pesticides into beer during dry hopping. BrewingSci. 67(January/February): 1-9.

Kodamatani, H., Yamazaki, S., Saito, K., Amponsaa-Karikari, A., Kishikawa, N., Kuroda, N., Tomiyasu, T., Komatsu, Y., 2009: Highly sensitive method for determination of $\mathrm{N}$-nitrosamines using high-performance liquid chromatography with online UV irradiation and luminol chemiluminescence detection. J. Chromatogr. A 1216(1): 92-98. https:// doi.org/10.1016/j.chroma.2008.11.025 
Krofta, K., Ježek, J., Kudrna, T., 2011: Content of elementary copper in hops after repeated applications of copper fungicides. Kvasný Průmysl 57(11-12): 417-423. https://doi.org/10.18832/kp2011045

Kroupová K., 2013: Stanovení methylrtuti v tělních tekutinách. Bakalářská práce, Masarykova universita, Brno.

Krska, R., Baumgartner, S., Josephs, R., 2001: The state-of-the-art in the analysis of type-A and -B trichothecene mycotoxins in cereals. Fresenius J. Anal. Chem. 371(3): 285-299. https://doi.org/10.1007/ s002160100992

Lachenmeier, D. W., Fügel, D., 2007: Reduction of nitrosamines in beer review of a success story. BrewingSci. 60 (May/June): 84-89.

Liang, P., Xu, J., Li., Q., 2008: Application of dispersive liquid-liquid microextraction and high performance liquid chromatography for the determination of three phthalate esters in water samples. Anal. Chim. Acta 609(1): 53-58. https://doi.org/10.1016/j. aca.2007.12.025

Lieu, P. T., Heiskala, M., Peterson, P. A., Yang, Y., 2001: The role of iron in health and disease. Mol. Aspects Med. 22: 1-87. https://doi. org/10.1016/S0098-2997(00)00006-6

Lopez, F. F., Cabrera, C., Lorenzo, M. L., Lopez, M. C., 1998: Aluminium levels in wine, beer and other alcoholic beverages consumed in Spain. Sci. Total Environ. 220(1): 1-9. https://doi.org/10.1016/S00489697(98)00214-9

Mahurpawar, M., 2015: Effects of Heavy Metals on Human Health. International Journal of Research - Granthaalayah, Social Issue and Environmental Problems: September: 1-7. ISSN- 2350-0530(0) ISSN2394-3629(P)

Manassaram, D. M., Backer, L. C., Moll, D. M., 2006: Review of Nitrates in Drinking Water: Maternal Exposure and Adverse Reproductive and Developmental Outcomes. Environ. Health Perspect. 114(3): 320327. https://doi.org/10.1289/ehp.8407

Martin S., Griswold W., 2009: Human health effects of heavy metals. Environmental Science and Technology briefs for citizens 15: 1-6.

Müller, A., Björklund, E., von Holst, C., 2001: On-line clean-up of pressurized liquid extracts for the determination of polychlorinated biphenyls in feedingstuffs and food matrices using gas chromatographymass spectrometry. J. Chromatogr. A 925(1-2): 197-205. https:// doi.org/10.1016/S0021-9673(01)01028-7

Nascentes, C. C., Kamogawa, M. Y., Fernandes, K. G., Arruda, M. A. Z., Nogueira, A. R. A., Nóbrega, J. A., 2005: Direct determination of $\mathrm{Cu}$ $\mathrm{Mn}, \mathrm{Pb}$, and $\mathrm{Zn}$ in beer by thermospray flame furnace atomic absorption spectrometry. Spectrochim. Acta B 60(5): 749-753. https://doi. org/10.1016/j.sab.2005.02.012

Orecchio, S., Paradiso Ciotti, V., Culotta L., 2009: Polycyclic aromatic hydrocarbons (PAHs) in coffee brew samples: Analytical method by GC-MS, profile, levels and sources. Food Chem. Toxicol. 47(4): 819826. https://doi.org/10.1016/j.fct.2009.01.011

Plaza-Bolaňos, P., Frenich, A. G., Martínez Vidal, J. L., 2010: Polycyclic aromatic hydrocarbons in food and beverages. Analytical methods and trends. J. Chromatogr. A 1217(41): 6303-6326. https://doi. org/10.1016/j.chroma.2010.07.079

Plum, L. M., Rink, L., Haase, H., 2010: The Essential toxin: Impact of Zinc on Human Health. Int. J. Environ. Res. Public Health 7(4): 13421365. https://doi.org/10.3390/ijerph7041342

Pohl P., 2008: Determination and fractionation of metals in beer: a review. Food Addit. Contam., Part A 25(6): 693-703. https://doi. org/10.1080/02652030701772323

Poli, A., Marangoni, F., Avogaro, A., Barba, G., Bellentani, S., Bucci, M., Cambieri, R., Catapano, A. L., Costanzo, S., Cricelli, C., de Gaetano, G., Di Castelnuovo, A., Faggiano, P., Fattirolli, F., Fontana, L., Forlani, G., Frattini, S., Giacco, R., La Vecchia, C., Lazzaretto, L., Loffredo, L., Lucchin, L., Marelli, G., Marrocco, W., Minisola, S., Musicco, M., Novo, S., Noz- zoli, C., Pelucchi, C., Perri, L., Pieralli, F., Rizzoni, D., Sterzi, R., Vettor R., Violi, F., Visioli, F., 2013: Moderate alcohol use and health: A consensus document. Nutr. Metab. Cardiovasc. Dis., 23(6): 487-504. https://doi.org/10.1016/j.numecd.2013.02.007

Poli, D., Manini, P., Andreoli, R., Franchini, I., Mutti, A., 2005: Determination of dichloromethane, trichloroethylene and perchloroethylene in urine samples by headspace solid phase microextraction gas chromatography - mass spectrometry. J. Chromatogr. B 820(1): 95-102. https://doi.org/10.1016/j.jchromb.2005.03.009

Romero, R., Bagur, M. G., Sánchez-Viñas, M., \& Gázquez, D., 2003: The influence of the brewing process on the formation of biogenic amines in beers. Anal. Bioanal. Chem. 376(2): 162-167. https://doi. org/10.1007/s00216-003-1885-2

Safe, S., 1989: Polychlorinated biphenyls (PCBs): mutagenicity and carcinogenicity. Mutat. Res. 220(1): 31-47. https://doi. org/10.1016/0165-1110(89)90007-9

Sawicki, C. R., Scaringelli, F. P., 1971: Colorimetric determination of nitrate after hydrazine reduction to nitrite. Microchem. J. 16(4): 657-672. https://doi.org/10.1016/0026-265X(71)90059-2

Sedláček, I., 2007: Taxonomie prokaryot. 1. vydání, Masarykova univerzita, Brno. ISBN 80-210-4207-9

Sergejevová M., Vaňková S., 2000: Sanace podzemní vody kontaminované chlorovanými alifatickými uhlovodíky; pilotní pokus, laboratorní testování. Vodní hospodářství 50(1): 14-17.

Smith, N. A., 1994: Cambridge prize lecture nitrate reduction and N-nitrosation in brewing. J. Inst. Brew. 100(5): 347-355. https://doi. org/10.1002/j.2050-0416.1994.tb00835.x

Száková, J., Kolihová, D., Miholová, D., Mader P., 2004: Single - purpose atomic absorption spectrometer AMA - 254 for Mercury determination and its performance in analysis of agricultural and environmental materials. Chem. Pap. 58(5): 311-315.

Tchounwou, P. B., Yedjou, C. G., Patlolla, A. K., Sutton, D. J., 2012: Heavy Metal Toxicity and the Environment: 133-164. in Luch, A.: Molecular, Clinical and Environmental Toxicology. Volume 3: Environmental Toxicology. Springer. ISBN 978-3-7643-8340-4

US FDA, 2005: CPG Sec. 510.600 Dimethylnitrosamine in Malt Beverages [online]. https://www.fda.gov/ICECI/ComplianceManuals/CompliancePolicyGuidanceManual/ucm074433.htm [cit. 2019-03-03]

Vanderhaegen, B., Neven, H., Verachtert, H., Derdelinckx, G., 2006: The chemistry of beer aging - a critical review. Food Chem. 95(3): 357381. https://doi.org/10.1016/j.foodchem.2005.01.006

Vaughan, A., O'Sullivan, T., van Sinderen, D., 2005: Enhancing the microbiological stability of malt and beer-a review. J. Inst. Brew. 111(4): 355-371. https://doi.org/10.1002/j.2050-0416.2005.tb00221.x

Vieira, E., Soares, M. E., Kozior, M., Krejpcio, Z., Ferreira, I. M. P. L. V. O., Lourdes Bastos, M., 2014: Quantification of total and hexavalent chromium in lager beers: Variability between styles and estimation of daily intake of chromium from beer. J. Agric. Food Chem. 62(37): 9195-9200. https://doi.org/10.1021/jf502657n

Vrzal, T., Olšovská, J., 2016: N-nitrosamines in 21th Century. Kvasný Průmysl 62(1): 2-8. https://doi.org/10.18832/kp2016001

Vrzal T., Olšovská J., 2019: Pyrolytic profiling nitrosamine specific chemiluminescence detection combined with multivariate chemometric discrimination for nontargeted detection and classification of nitroso compounds in complex samples. Anal. Chim. Acta, in press, https://doi.org/10.1016/j.aca.2019.01.033

Walters, C. L., Hart, R. J., Smith, P. L. R., 1983: Analysis of total N-nitroso compounds as a group by denitrosation to nitric oxide, with detection using a chemiluminescence analyser: 295-308. in Preussmann, R., O’Neill, I. K., Eisenbrand, G., Spiegelhalder, G., Bartsch, H.: Environmental Carcinogens - Selected Methods of Analysis for N-Nitroso Compounds. IARC Sci. Publ. No. 45. 
Wolf-Hall, C. E., 2007: Mold and mycotoxin problems encountered during malting and brewing. Int. J. Food Microbiol 119(1-2): 89-94. https://doi.org/10.1016/j.ijfoodmicro.2007.07.030

Wypych, J., Mańko, T., 2002: Determination of Volatile Organic Compounds (VOCs) in Water and Soil Using Solid Phase Microextraction. Chem. Anal. (Warsaw, Pol.) 47(4): 507-530.

Ye, C.-W., Gao, J., Yang, C., Liu, X.-J., Li, X.-J., Pan, S.-Y., 2009: Development and application of an SPME/GC method for the determination of trace phthalates in beer using a calix[6]arene fiber. Anal. Chim. Acta 641(1-2): 64-74. https://doi.org/10.1016/j.aca.2009.02.052

Žabka, M., Jegorov, A., 2002: Návrat houby, jež dala vzniknout jménu trichotheceny. Chemické listy 96(7): 607-610.
Zákon 110/1997 Sb. o potravinách a tabákových výrobcích

Zhao, Y.-Y., Boyd, J., Hrudey S. E., Li X.-F., 2006: Characterization of New Nitrosamines in Drinking Water Using Liquid Chromatography Tandem Mass Spectrometry. Environ. Sci. Technol. 40(24):7636-7641. https://doi.org/10.1021/es061332s

Zöllner, P. and Mayer-Helm, B., 2006: Trace mycotoxin analysis in complex biological and food matrices by liquid chromatography-atmospheric pressure ionisation mass spectrometry. J. Chromatogr. A 1136(2): 123-169. https://doi.org/10.1016/j.chroma.2006.09.055 